\title{
Effect of lactic acid and acetic acid on the quality of local meat \\ By
}

Azza, A. EL-Tabiy and Zienab, I. Soliman

Food Hygiene Department, Port-Said Lab., Animal Health Research Institute, Dokki, Giza, Egypt.

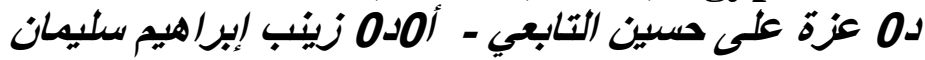
تأثير حمض اللاكتيك وحمض الخلّيك على جودة اللحوم البقرية المئية المحلية

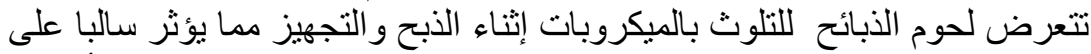

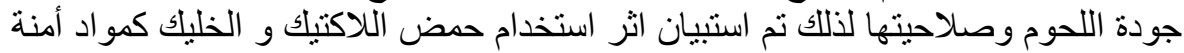

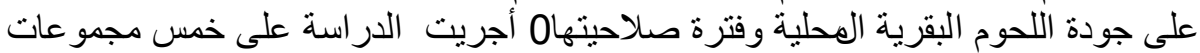

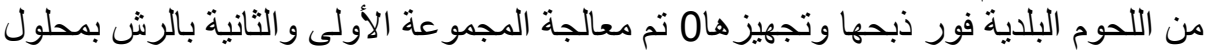

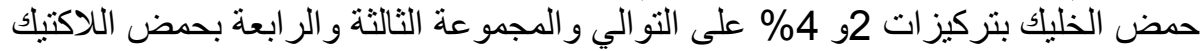

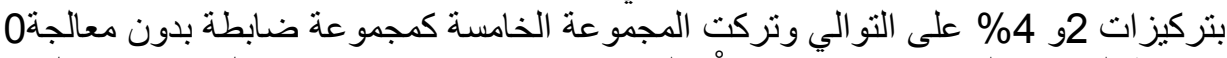

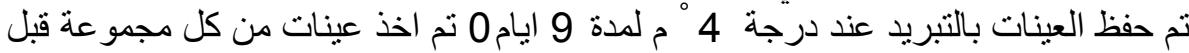

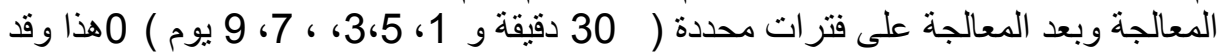

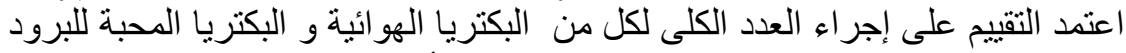

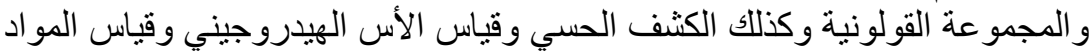

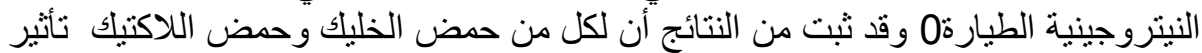

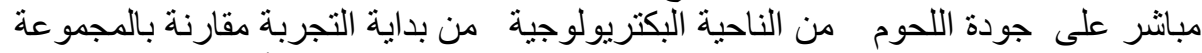

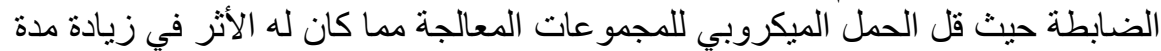

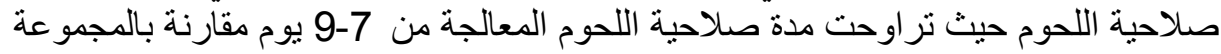

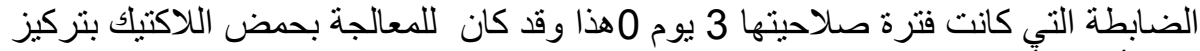

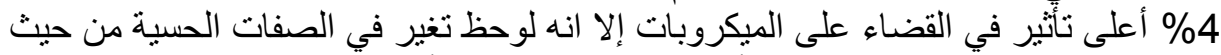

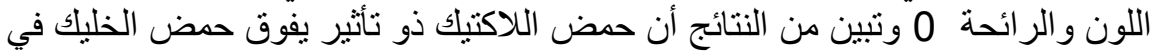

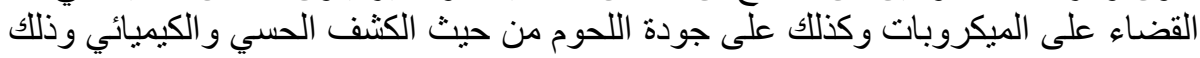

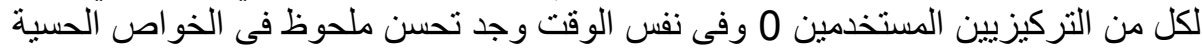
فى المجمو عة التى تم معالجتها بحامض التلاكتيك بتركيز

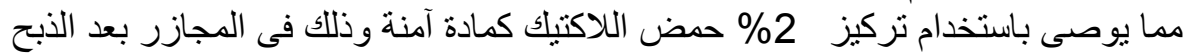

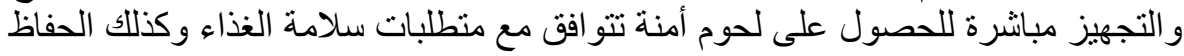

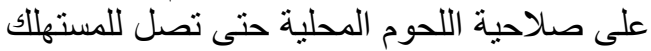

\section{ABSTRACT}

Effect of lactic acid and acetic acid spray on the quality and shelf-life extension of fresh beef stored at $4^{\circ} \mathrm{C}$ was investigated. Lactic and acetic acid were sprayed over the meat at various concentrations of 0 (control), 2\% lactic acid (L.A.), 4\% L.A, 2\% acetic acid (A.A.) and 4\% A.A. then stored at $4^{\circ} \mathrm{C}$ for 9 days. Samples were examined in the fresh 
state (0 day), prior to spay. At specified time (30 min,1, 3, 5, 7 and 9 days), samples were analyzed for microbial counts, sensorial properties, $\mathrm{pH}$ and total volatile basic nitrogen(TVB-N). Bacterial groups count to indicate effectiveness of treatments included aerobic plate counts (APCs), Psychrophilic counts (PTCs) and total coliform counts (TCCs).Since the beginning of the experiment, the inhibitory effect of lactic acid and acetic acid has been observed. Lactic and acetic acid reduced the microbial counts immediately after the treatment and retarded microbial growth during storage. At first day of display, APCs were reduced by 1.5 to $3 \log$ cycles, $\log$ psychrophilic counts were consistently reduced and $\log$ coliform counts were reduced to undetectable levels in acid treated groups. The inhibitory effect on bacterial growth was pronounced when the concentration of lactic acetic and lactic acids increased. Acetic and lactic acid treatments improved the microbiological and physicochemical qualities of meat and consequently prolongs their shelf life. Shelf-life of acid treated samples from microbial quality standpoints was $7-9$ days according to treatment used against 3 days in untreated samples. Four percent lactic acid treatments appeared to be more effective in delaying the microbial growth however; meat sample could not keep their color and odor.

Comparing the effects of the two acids treatments, lactic acid was found to be more effective in both concentrations used. Lactic acid sprayed samples, particularly with $2 \%$, showed the greater acceptability than did those sprayed with acetic acid throughout the storage days. From microbial and visual quality standpoints, meat sample sprayed with $2 \%$ seemed to be more acceptable regarding meat color and bacterial numbers with proper hygiene and handling procedures could provide safer meat with good quality and to ensure safe public health.

\section{INTRODUCTION}

Fresh meat has unique biological and chemical properties and its nutrients composition represents an optimum medium for microbial growth. The deep tissues of meat carcasses are instrincally sterile with the majority of microorganisms being found on the skin or any surfaces exposed during slaughter processing (Gill, 1980). Meat carcasses may become contaminated from fecal material, paunch contents and the hide ( Lahr ,1996). Additional sources of cross contamination exist in the slaughter process such as processing tools and equipment, a structural 
component of the facility, human contact and carcass-to-carcass contact (Institute of Food Technologists, 2002).

Fresh meat has a short shelf life due to microbial spoilage of both pathogenic and non-pathogenic (Dickson and Anderson, 1992).Spoilage can be defined as any change in a food product that makes it unacceptable to the consumer from a sensory point of view (Gram et al., 2002). In the case of meat, microbial spoilage leads to the development of off-odors and often slime formation, which make the product undesirable for human consumption (Hilario et al., 2004).

The color of fresh meat is an important quality parameter that determines a consumer's response and decision to buy or not to buy that product at retail. The bright red oxygenated form of oxymyoglobin is most commonly associated with desirability in fresh beef, while oxidation of heme iron to its ferric state (metmyoglobin) is a prime factor in unacceptability as judged by consumers(Strange et al., 1974).According to Seideman et al. (1984) the discoloration of meat is predominately due to bacterial growth and reduced oxygen tensions which facilitate the formation of metmyoglobin. The development of organoleptic spoilage is related to microbial consumption of meat nutrients such as sugars and free amino acids and the release of undesired volatile metabolites. Total volatile basic nitrogen (TVB-N) values could potentially be used as indicators in predicting the microbial quality of beef during chilled storage under aerobic conditions (Byun et al., 2003).

Since microbial growth in beef and its products occurs primarily at the surface, attempts have been made to delay spoilage by using an organic acid spray or dips as antimicrobial agents (Siragusa and Dickson,1992).Lactic acid and acetic acid have been used as food preservatives and are generally recognized as safe (Branen et al., 1990). Solutions of lactic and acetic acid are commonly used by the slaughter industry as antimicrobial spray wash interventions to reduce the microbial load on freshly slaughtered carcasses (Berry and Cutter, 2000). The effectiveness of organic acids is best achieved shortly after hide removal when the carcass is still warm (Huffman, 2002).In the US, organic acids are applied as part of a carcass wash pre-chill (USDA/FSIS, 2004).

Several studies demonstrated the effectiveness of lactic acid as an antimicrobial intervention in red meat processing (Hardin et al., 1995). The natural content of lactic acid in meat is approximately $10 \mathrm{~g} / \mathrm{kg}$ it contributes to the flavor of meat and owing to its antimicrobial effects and keeping quality (Bolder, 1997). The advantage of using lactic acid is 
that it does not require the use of high pressure spraying to eliminate the pathogens from meat carcasses. In addition, it remains on the meat carcasses, and works as antimicrobial agent on carcass surfaces (Ramirez et al.,2001).Moreover, the lactate anion slows down the growth of surviving microbes during storage (Dincer and Baysa, 2004).

Acetic acid is a mono carboxylic acid with a pungent odor and taste. It is commonly known as vinegar which has antimicrobial capabilities due to its ability to lower the $\mathrm{pH}$ and cause instability of bacterial cell membranes (Jay, 1992).

The mode of action of organic acid is that the undissociated acid penetrate the cell of microorganisms by means of diffusion and then dissociates and acidify the cell interior, thus interfering with cellular metabolism or decreasing the biological activity as a result of $\mathrm{pH}$ changes of the cell's environments (Cherrington, et al.,1991). The ultimate $\mathrm{pH}$ of meat was significant for its resistance to spoilage because most bacteria grow optimally at about $\mathrm{pH} 7$ and not well below $\mathrm{pH} 4$ or above $\mathrm{pH} 9$ (Walker and Betts, 2000).According to many studies the ultimate $\mathrm{pH}$ and meat color are the most important indices of meat quality (Brunso et al., 2005) .

Consumers demand high quality, natural, nutritious, fresh appearance and convenient meat with natural flavor and taste and an extended shelf-life. To match all these demands without compromising safety. Generally, the quality of beef can be based on color, odor, appearance, taste, culinary properties as well as bacteriological status (Eneji et al., 2007).Therefore, the present study was undertaken to evaluate effect of lactic and acetic acids spray on microbial, sensory and physico-chemical qualities and on shelf-life of fresh meat .

Materials and Methods

.Acetic and lactic acid spray solutions :

Normal household vinegar contains 5\% acetic acid and lactic acid (Loba Chemie Pvt, Ltd., 88\% ) were used .Acid spray solutions were prepared fresh on the day of use. Solution for spray ( $2 \%$ and $4 \%$ ) were prepared by dilution of acetic acid and lactic acid in tap water. A manual sprayer was used for application of the solution to the meat surface. Meat surface sections were sprayed with 2, $4 \%$ acid solutions at an amount $2 \mathrm{ml}$ per $100 \mathrm{gm}$ (Sundar and Zhang, 2006).

2.2.Experimental samples:

Twenty five kilograms of fresh beef were obtained from recent slaughtered animal after arrival of the meat to butcher's shop in Port Said, Egypt. The collected meat was taken from hindquarter after preparation (without visible fat).Meat was rapidly transferred as possible 
to laboratory in ice box with minimum delay. Samples were divided into five groups. Meat samples were thoroughly rinsed with tap water before the acid spray was applied. The first and second groups were sprayed with $2 \%$ and $4 \%$ lactic acid respectively. Third and forth groups were sprayed with $2 \%$ and $4 \%$ acetic acid respectively. The fifth group was kept as controls, untreated sample.

\subsection{Sampling}

A representative parts from each group was examined for background bacterial levels ,in the fresh state ( 0 day) prior to spray. After packaging, samples were stored at $4{ }^{\circ} \mathrm{C}$ ( 9 days).At specified time intervals (30 $\mathrm{min}, 1,3,5,7$ and $9^{\text {th }}$ days of display), samples were withdrawn and assessed for aerobic plate count(APCs), psychrophilic counts(PTCs) ,total coliforms count (TCCs), $\mathrm{pH}$, total volatile basic nitrogen(TVB-N) and sensory attributes. Five replications were performed for each group.

\subsection{Bacteriological analysis}

Meat samples of $25 \mathrm{~g}$ were aseptically removed from the bags and homogenized in $225 \mathrm{ml}$ of sterile peptone water $(0.1 \%)$ for $1 \mathrm{~min}$ using a Stomacher. From this homogenate, decimal serial dilutions were made in the same sterile peptone water and used for microbiological analyses of the beef samples at each of the appropriate time intervals during refrigerated storage. Aerobic plate counts (APCs) were determined by inoculating $0.1 \mathrm{ml}$ of the sample homogenate, at selected dilutions, onto duplicate sterile plates of plate count agar using the surface spread technique, then the plates were incubated for $72 \mathrm{~h}$ at $30^{\circ} \mathrm{C}$ (ISO: 4833, 2003,Standard).Psychrophilic counts (PTC) were determined in a similar method to that for APC except that plates were incubated at $5^{\circ} \mathrm{C}$ for 10 days. (ISO: 17410,2001, Standard).To determine total coliforms counts (TCCs), $1 \mathrm{ml}$ of the appropriate dilution was inoculated by the pour-plated method on violet red bile agar and overlaid with approximately $5 \mathrm{ml}$ of the same growth medium then the plates were incubated at $37^{\circ} \mathrm{C}$ for $24 \mathrm{~h}$.(ISO: 4832,2006 , Standard). Colonies were counted and expressed as $\log _{10}$ forming units $\left(\log _{10} \mathrm{CFU}\right) / \mathrm{g}$ of meat.

\subsection{Sensory analysis}

Sensory characteristics of samples were investigated by 9 panelists in food hygiene department, Port-Said, lab to color and odor at the same display intervals of bacteriological analysis. Evaluation was performed under white fluorescent light. Sample being judged for color was placed in a glass Petri dish and viewed under daylight fluorescent light against a neutral gray background. For odor evaluation, a portion of 
the meat sample was presented in glass stoppered125-ml Erlenmeyer flasks wrapped in tissue to mask appearance. The odors of samples were judged in air-conditioned. Five replicates of each sample were submitted to the sensory analysis.

A 5-point structured hedonic scale was used to score the following: where (5) is the best and (1) is the lowest. Sensory panelists evaluated overall color $(5=$ bright red, $4=$ dull red, $3=$ slightly brownish red, $2=$ moderately brownish red, $1=$ brown) .Panelists also evaluated beef odor $(5=$ no off odor, $4=$ slight off odor, $3=$ small off odor, $2=$ moderate off odor, and 1=extreme off odor) (Hunt et al., 1991).

Panel members were also asked to note whether the meat samples were acceptable or unacceptable in overall appearance following AMSA (1991) guidelines. 8=Extremely desirable, 7= desirable, $6=$ moderately desirable, $5=$ slightly desirable, $4=$ slightly undesirable , $3=$ moderately undesirable, $2=$ undesirable, $1=$ Extremely undesirable .Each package was evaluated until at least $80 \%$ of the samples in that group had been assigned a mean overall appearance score of 3 (moderately undesirable) or lower. The development of unpleasant odor, color, softening, and the formation of a sticky layer on the surface were evaluated as the indicators of spoilage.

\subsection{Determination of $\mathrm{pH}$ :}

Meat samples (10 g) from each treatment $(n=5 /$ treatment $)$ at each sampling day were separately homogenized with $100 \mathrm{ml}$ of distilled water in a stomacher. The $\mathrm{pH}$ of the homogenates was measured using a $\mathrm{pH}$ electrode attached to a $\mathrm{pH}$ meter (AOAC ,1984).

2.7. Total volatile bases nitrogen (TVB-N) determination:

Total volatile bases nitrogen (TVB-N) content was determined according to method described by Inal (1992).

\subsection{Statistical Analysis:}

Mean and standard error of mean were used to describe data. One-Way ANOVA test was used to compare the effects of different treatments .P value was considered significant if less than 0.05 and highly significant if less than 0.01 . These tests were analyzed using the Statistical Package for Social Scientists (SPSS) for windows 16.0 (SPSS Inc., Chicago, IL, and USA). 


\section{RESULTS}

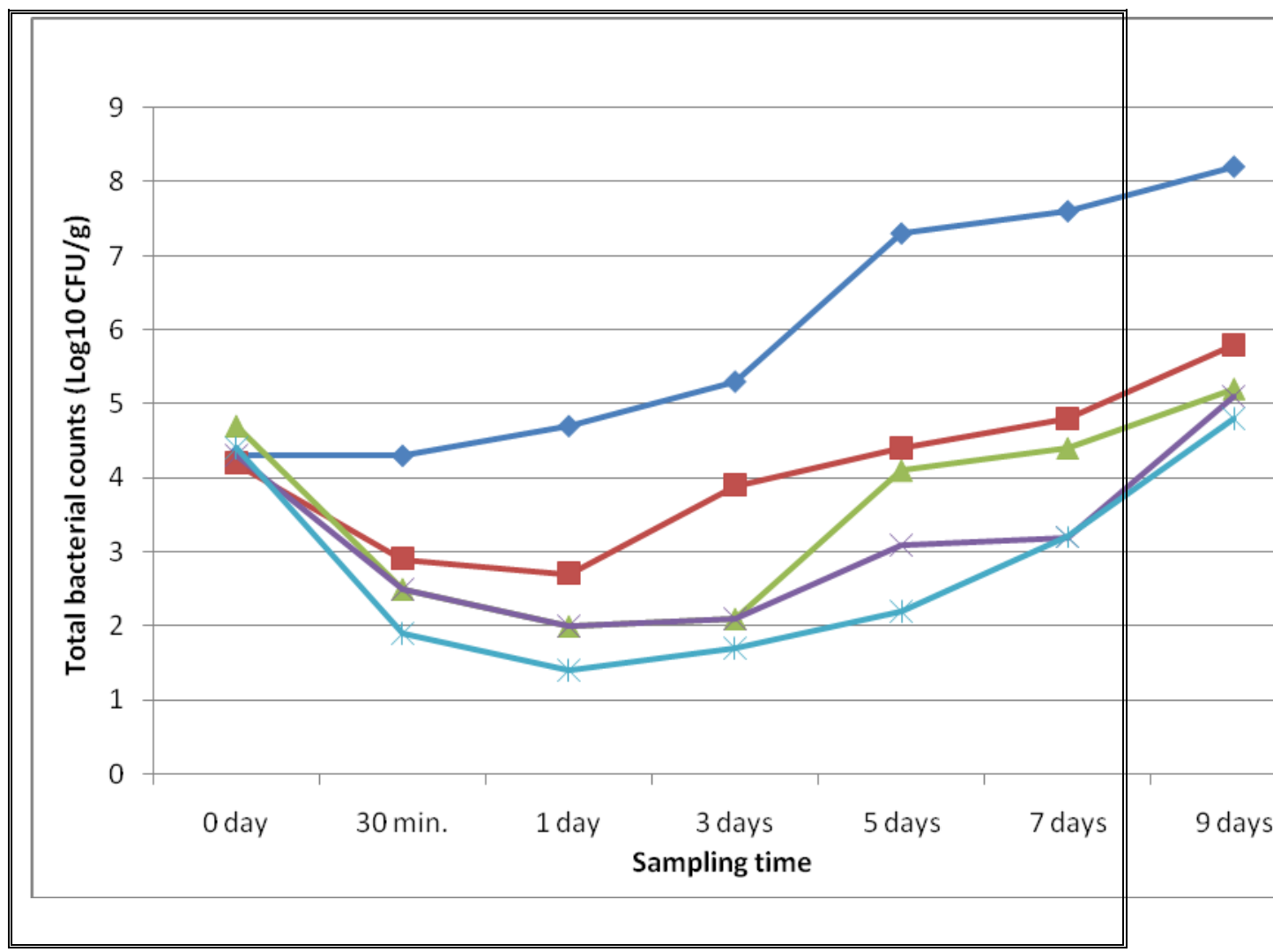

Fig. (1): Mean aerobic plate counts $\left(\log _{10} \mathrm{CFU} / \mathrm{g}\right)$ of control and acid treated beef during storage at $4^{\circ} \mathrm{C}(\mathrm{n}=5)$.
A.A.: Acetic acid
L.A. : Lactic acid 
Assiut Vet Med.J.Vol. 57No.130 July 2011

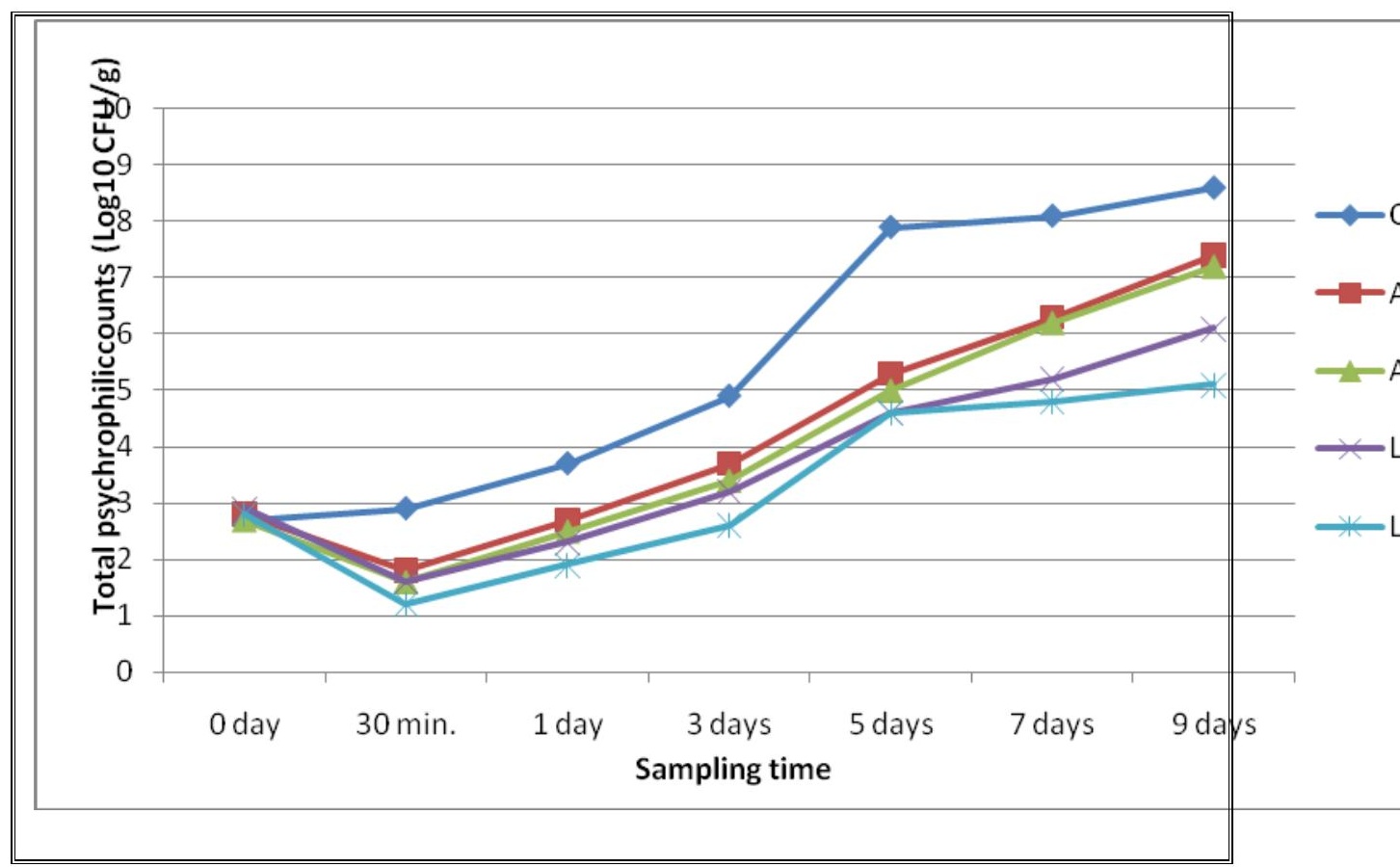

Fig.(2): Mean psychrophilic counts $\left(\log _{10} \mathrm{CFU} / \mathrm{g}\right)$ for control and acid sprayed beef during storage at $4^{\circ} \mathrm{C}(\mathrm{n}=5)$.
A.A.: Acetic acid
L.A. : Lactic acid 


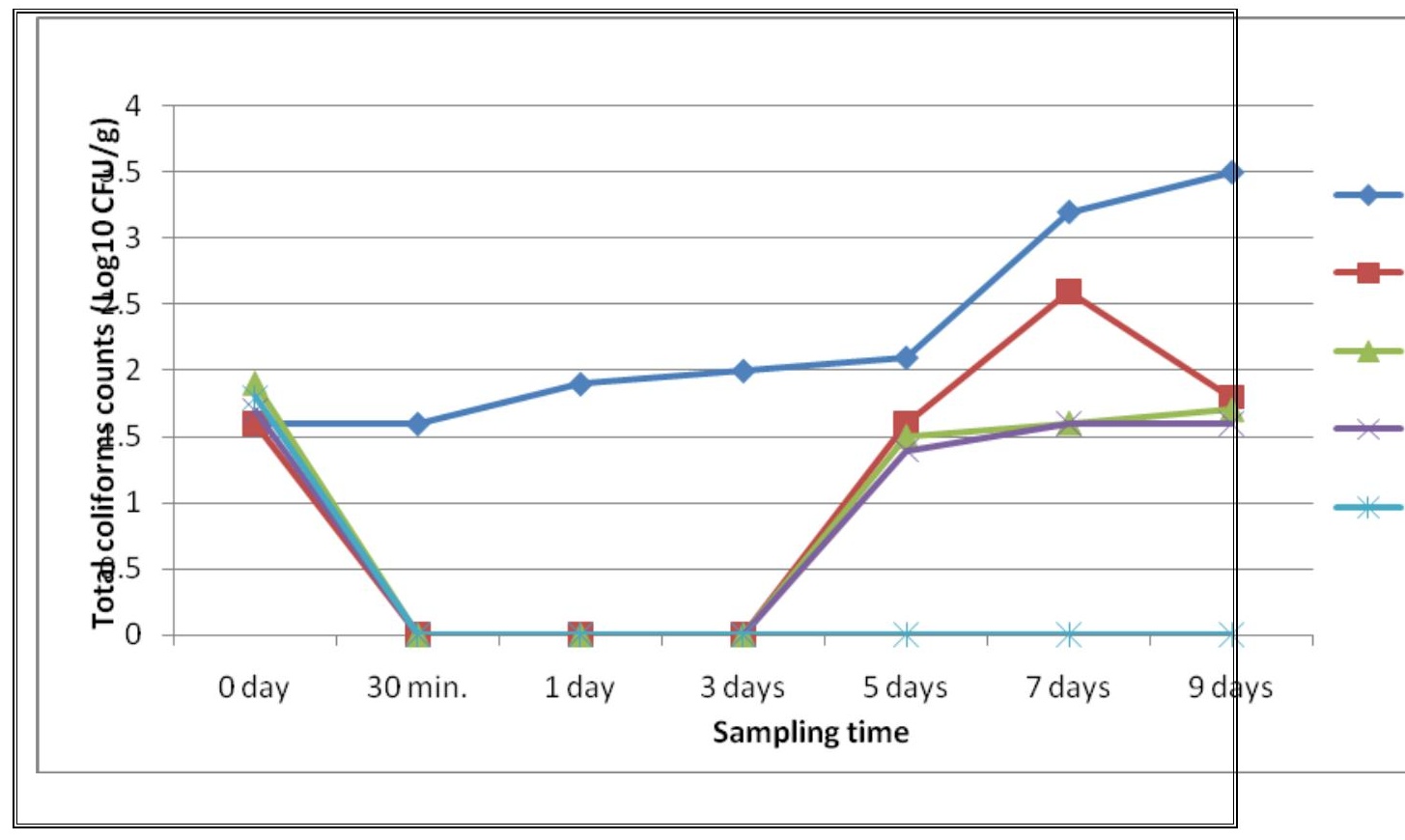

Fig (3): Mean total coliforms counts $\left(\log _{10} \mathrm{CFU} / \mathrm{g}\right)$ for control and acid treated beef during storage at $4^{\circ} \mathrm{C}(\mathrm{n}=5)$.
A.A.: Acetic acid
L.A. : Lactic acid

Table (1): Mean color evaluation scores for control and acid treated beef during storage at $4^{\circ} \mathrm{C}(\mathrm{n}=5)$.

\begin{tabular}{|c|c|c|c|c|c|}
\hline $\begin{array}{l}\text { Storage } \\
\text { period }\end{array}$ & Control & 2\%A.A. & 4\% A.A. & $2 \%$ L.A. & 4\%L.A. \\
\hline $\mathbf{0}$ & $4.8 \pm 0.12$ & $4.7 \pm 0.11$ & $4.7 \pm 0.12$ & $4.7 \pm 0.18$ & $4.6 \pm 0.16$ \\
\hline 30 min. & $4.7 \pm 0.12$ & $4.0 \pm 0.16 *$ & $3.5 \pm 0.13 * *$ & $4.7 \pm 0.15$ & $4 \pm 0.18 *$ \\
\hline 1 day & $4.6 \pm 0.14$ & $3.5 \pm 0.18 * *$ & $3.2 \pm 0.18 * *$ & $4.8 \pm 0.13$ & $4 \pm 0.11$ \\
\hline 3 day & $2.3 \pm 0.18$ & $3.0 \pm 0.15^{*}$ & $2.5 \pm 0.18 *$ & $4.9 \pm 0.1 * *$ & $4 \pm 0.18 * *$ \\
\hline 5 day & $1 \pm 0.18$ & $2.1 \pm 0.18 * *$ & $2.0 \pm 0.12 * *$ & $4.5 \pm 0.18 * *$ & $4 \pm 0.15 * *$ \\
\hline 7 day & NA & $1.2 \pm 0.18$ & $1.5 \pm 0.18$ & $3.5 \pm 0.16$ & $3.6 \pm 0.16$ \\
\hline 9 day & NA & $1.0 \pm 0.00$ & $1.0 \pm 0.00$ & $2.5 \pm 0.12$ & $3.0 \pm 0.12$ \\
\hline
\end{tabular}

$\mathrm{NA}=$ Not analyzed (Rejected), A.A.: Acetic acid, L.A.: Lactic acid

Overall color $(5=$ Bright red, $4=$ Pale red, $3=$ slightly brownish red, $2=$ moderately brownish red, $1=$ Brown). 
*:Significant correlation at $\mathrm{P}<0.05$, relative to control at the same storage period.

**:Highly Significant correlation at $\mathrm{P}<0.01$, relative to control at the same storage

period.

Table (2): Mean ( \pm SE) odor evaluation scores for control and acid treated beef during storage at $4^{\circ} \mathrm{C}(\mathrm{n}=5)$.

\begin{tabular}{|c|c|c|c|c|c|}
\hline $\begin{array}{l}\text { Storage } \\
\text { period }\end{array}$ & Control & $2 \%$ A.A. & 4\% A.A. & $2 \%$ L.A. & 4\% L.A. \\
\hline $\mathbf{0}$ & $4.9 \pm 0.18$ & $4.8 \pm 0.18$ & $4.9 \pm 0.18$ & $4.9 \pm 0.18$ & $4.9 \pm 0.18$ \\
\hline $30 \mathrm{~min}$. & $4.9 \pm 0.18$ & $3.2 \pm 0.18 * *$ & $2.5 \pm 0.18 * *$ & $4.5 \pm 0.13$ & $3.8 \pm 0.20$ \\
\hline 1 day & $3.6 \pm 0.18$ & $3.1 \pm 0.18 *$ & $2.4 \pm 0.18 * *$ & $4.1 \pm 0.18 *$ & $3.7 \pm 0.18$ \\
\hline 3 day & $2 \pm 0.18$ & $3 \pm 0.18 * *$ & $3 \pm 0.18 * *$ & $4.1 \pm 0.18^{* *}$ & $3.5 \pm 0.18 *$ \\
\hline 5 day & $1 \pm 0.18$ & $3.2 \pm 0.18 * *$ & $3 \pm 0.18 * *$ & $3.6 \pm 0.18 * *$ & $3.2 \pm 0.18 *$ \\
\hline 7 day & NA & $2 \pm 0.18$ & $2.5 \pm 0.18$ & $3.2 \pm 0.18$ & $3.1 \pm 0.18$ \\
\hline 9 day & NA & $1 \pm 0.18$ & $1.2 \pm 0.18$ & $3.1 \pm 0.18$ & $2.6 \pm 0.18$ \\
\hline
\end{tabular}

$\mathrm{NA}=$ Not analyzed(Rejected), A.A. :Acetic acid , L.A. : Lactic acid

NB: Off-odor $=$ Any change in odor

Odor score : $5=$ no off odor, $4=$ slight off odor, $3=$ small off odor, $2=$ moderate off odor,

\section{$1=$ extreme off odor.}

*:Significant correlation at $\mathrm{P}<0.05$, relative to control at the same storage period.

**: Significant correlation at $\mathrm{P}<0.01$, relative to control at the same storage period.

Table (3) : Overall appearance score of meat samples during storage.

\begin{tabular}{|c|c|c|c|c|c|}
\hline $\begin{array}{c}\text { Storage } \\
\text { period }\end{array}$ & Control & $2 \%$ A.A. & 4\% А.А. & 2\%L.A. & 4\%L.A. \\
\hline 0 & $7.8 \pm 0.12$ & $7.9 \pm 0.15$ & $7.7 \pm 0.15$ & $7.7 \pm 0.15$ & $7.8 \pm 0.15$ \\
\hline 30 min. & $7.9 \pm 0.15$ & $7 \pm 0.15$ & $6.5 \pm 0.13$ & $7.9 \pm 0.15$ & $6.9 \pm 0.15$ \\
\hline 1 day & $6.5 \pm 0.13$ & $6 \pm 0.15$ & $6.0 \pm 0.05$ & $7.9 \pm 0.13$ & $6.4 \pm 0.15$ \\
\hline 3 day & $4.8 \pm 0.15$ & $6 \pm 0.05$ & $5.2 \pm 0.04$ & $7.9 \pm 0.12$ & $6.2 \pm 0.15$ \\
\hline 5 day & $3.2 \pm 0.13$ & $5.1 \pm 0.05$ & $4.9 \pm 0.15$ & $6.3 \pm 0.15$ & $6.2 \pm 0.15$ \\
\hline 7 day & $1 \pm 0.00$ & $4.0 \pm 0.03$ & $3.7 \pm 0.15$ & $5.4 \pm 0.15$ & $5.3 \pm 0.15$ \\
\hline
\end{tabular}




\begin{tabular}{|c|c|c|c|c|c|}
\hline 9 day & NA & $\mathbf{3 . 0} \pm \mathbf{0 . 1 2}$ & $\mathbf{2 . 7} \pm \mathbf{0 . 0 5}$ & $\mathbf{3 . 4 \pm 0 . 1 5}$ & $\mathbf{3 . 6 \pm 0 . 1 5}$ \\
\hline
\end{tabular}

$\mathrm{NA}=$ Not analyzed(Rejected), A.A. :Acetic acid, L.A. : Lactic acid

Overall appearance score :8=Extremely desirable, $7=$ desirable , $6=$ moderately desirable, $5=$ slightly desirable, $4=$ slightly undesirable , 3= moderately undesirable, 2= undesirable, 1= Extremely undesirable

A mean score of 3 ("moderately undesirable") or lower was considered the point at which samples would be considered unacceptable.

*:Significant correlation at $\mathrm{P}<0.05$, relative to control at the same storage period.

**: Significant correlation at $\mathrm{P}<0.01$, relative to control at the same storage period.

Table (4):Effects of acid treatments and storage time on the $\mathrm{pH}$ of meat samples during

refrigerated storage at $4^{\circ} \mathrm{C}(\mathrm{n}=5)$.

\begin{tabular}{|c|c|c|c|c|c|}
\hline $\begin{array}{l}\text { Storag } \\
\text { e time }\end{array}$ & Control & A.A.2\% & A.A. 4\% & L.A.2\% & L.A. 4\% \\
\hline $\mathbf{0}$ & $\begin{array}{c}5.75 \pm 0.0 \\
1 \\
\end{array}$ & $5.73 \pm 0.01$ & $5.73 \pm 0.01$ & $5.74 \pm 0.01$ & $5.74 \pm 0.01$ \\
\hline 30min & $\begin{array}{c}5.89 \pm 0.1 \\
0\end{array}$ & $\begin{array}{c}4.94 \pm 0.20 * \\
*\end{array}$ & $\begin{array}{c}4.82 \pm 0.30 * \\
*\end{array}$ & $\begin{array}{c}5.12 \pm 0.10 \\
*\end{array}$ & $\begin{array}{c}5.04 \pm 0.10 \\
*\end{array}$ \\
\hline 1 day & $\begin{array}{c}5.88 \pm 0.2 \\
0\end{array}$ & $4.85 \pm 0.20 *$ & $4.75 \pm 0.20 *$ & $5.05 \pm 0.10 *$ & $5.03 \pm 0.10 *$ \\
\hline 3 days & $\begin{array}{c}5.74 \pm 0.1 \\
0\end{array}$ & $4.72 \pm 0.20 *$ & $4.67 \pm 0.10 *$ & $5.39 \pm 0.10$ & $5.12 \pm 0.20$ \\
\hline 5 day & $\begin{array}{c}6.58 \pm 0.1 \\
0 \\
\end{array}$ & $\begin{array}{c}4.88 \pm 0.20 * \\
*\end{array}$ & $\begin{array}{c}4.74 \pm 0.20 * \\
* \\
\end{array}$ & $\begin{array}{c}5.40 \pm 0.20 * \\
* \\
\end{array}$ & $\begin{array}{c}5.30 \pm 0.20 * \\
* \\
\end{array}$ \\
\hline 7 day & $\begin{array}{c}6.68 \pm 0.1 \\
0 \\
\end{array}$ & $\begin{array}{c}5.17 \pm 0.02 * \\
* \\
\end{array}$ & $\begin{array}{c}5.06 \pm 0.02 * \\
* \\
\end{array}$ & $\begin{array}{c}5.85 \pm 0.01 * \\
*\end{array}$ & $\begin{array}{c}5.37 \pm 0.02 * \\
* \\
\end{array}$ \\
\hline 9 day & $\begin{array}{c}6.72 \pm 0.1 \\
0\end{array}$ & $\begin{array}{c}5.47 \pm 0.02 * \\
*\end{array}$ & $\begin{array}{c}5.40 \pm 0.02 * \\
*\end{array}$ & $\begin{array}{c}5.90 \pm 0.01 * \\
*\end{array}$ & $\begin{array}{c}5.90 \pm 0.01 \\
*\end{array}$ \\
\hline
\end{tabular}

A.A. : Acetic acid , L.A. : Lactic acid

*:Significant correlation at $\mathbf{P}<\mathbf{0 . 0 5}$, relative to control at the same storage period.

**: Significant correlation at $\mathbf{P}<0.01$, relative to control at the same storage period. 
Table (5): Total volatile bases nitrogen $(\mathrm{mg} / 100 \mathrm{~g})$ contents of control and acid treated

samples during storage $(n=5)$.

\begin{tabular}{|c|c|c|c|c|r|}
\hline $\begin{array}{c}\text { Storage } \\
\text { period }\end{array}$ & Control & $2 \%$ A.A. & $4 \%$ A.A. & $2 \%$ L.A. & $4 \%$ L.A \\
\hline 0 & $\mathbf{3 . 6 0} \pm \mathbf{0 . 0 3}$ & $\mathbf{3 . 4 9} \pm \mathbf{0 . 0 3}$ & $\mathbf{3 . 6 7} \pm \mathbf{0 . 0 3}$ & $\mathbf{3 . 5 7} \pm \mathbf{0 . 0 3}$ & $\mathbf{3 . 5 5} \pm \mathbf{0 .}$ \\
\hline $\mathbf{3 0}$ min. & $\mathbf{6 . 4 4} \pm \mathbf{0 . 2 0}$ & $\mathbf{3 . 5 7} \pm \mathbf{0 . 2 3} * *$ & $\mathbf{3 . 6 7} \pm \mathbf{0 . 3 1} * *$ & $\mathbf{3 . 5 7} \pm \mathbf{0 . 3 3} * *$ & $\mathbf{3 . 5 9} \pm \mathbf{0 . 3}$ \\
\hline 1 day & $\mathbf{1 2 . 5 5} \pm \mathbf{0 . 5 0}$ & $\mathbf{7 . 6 9} \pm \mathbf{0 . 3 1} * *$ & $\mathbf{6 . 5 2} \pm \mathbf{0 . 3 3} * *$ & $\mathbf{6 . 6 9} \pm \mathbf{0 . 3 6} * *$ & $\mathbf{5 . 9 7} \pm \mathbf{0 . 3}$ \\
\hline $\mathbf{3}$ day & $\mathbf{1 6 . 5 5} \pm \mathbf{0 . 5 5}$ & $\mathbf{1 2 . 2 0} \pm \mathbf{0 . 3 5} * *$ & $\mathbf{1 0 . 9 7} \pm \mathbf{0 . 2 7} * *$ & $\mathbf{1 1 . 2 0} \pm \mathbf{0 . 3 3} * *$ & $\mathbf{9 . 2 7} \pm \mathbf{0 . 3 0}$ \\
\hline 5 day & $\mathbf{2 5 . 8 9} \pm \mathbf{0 . 6 3}$ & $\mathbf{1 7 . 0 2} \pm \mathbf{0 . 3 8} * *$ & $\mathbf{1 5 . 9 4} \pm \mathbf{0 . 3 5} * *$ & $\mathbf{1 6 . 2 3} \pm \mathbf{0 . 3 8} * *$ & $\mathbf{1 1 . 2 3} \pm \mathbf{0 . 3}$ \\
\hline $\mathbf{7}$ day & $\mathbf{2 7 . 4 3} \pm \mathbf{0 . 6 3}$ & $\mathbf{2 1 . 4 2} \pm \mathbf{0 . 2 3} * *$ & $\mathbf{2 0 . 5 1} \pm \mathbf{0 . 3 3} * *$ & $\mathbf{2 0 . 4 4} \pm \mathbf{0 . 0 3} * *$ & $\mathbf{1 5 . 4 9} \pm \mathbf{0 . 3}$ \\
\hline 9 day & $\mathbf{2 7 . 4 8} \pm \mathbf{0 . 6 5}$ & $\mathbf{2 6 . 2 4} \pm \mathbf{0 . 1 0}$ & $\mathbf{2 5 . 1 2} \pm \mathbf{0 . 0 3}$ & $\mathbf{2 4 . 5 1} \pm \mathbf{0 . 0 3} *$ & $\mathbf{2 2 . 2 3} \pm \mathbf{0 . 3}$ \\
\hline
\end{tabular}

A.A. : Acetic acid , L.A. : Lactic acid

*:Significant correlation at $\mathbf{P}<0.05$, relative to control at the same storage period.

**: Significant correlation at $\mathbf{P}<0.01$, relative to control at the same storage period.

4.Discussion:

4.1.Microbiological evaluation:

Microbiological quality of control and treated meat samples were determined based on aerobic plate count (APCs ), psychrophilic count (PTCs) and total coliform counts (TCCs) .

4.1.1. Aerobic plate counts:

Mean aerobic plate counts $\left(\log _{10} \mathrm{CFU} / \mathrm{g}\right)$ for control and for treatment beef sample groups at storage intervals were graphically represented in Fig. (1). The initial total bacterial count (before spray, 0 time) ranged from 4.3 to $4.7 \log _{10} \mathrm{CFU} / \mathrm{g}$, indicated acceptable quality meat samples. Since the beginning of the experiment the inhibitory effect of lactic acid and acetic acid has been observed. After 30 min of acid spray, all samples treated with acid showed significant reduction of the initial bacterial counts $(\mathrm{P}<0.05)$. The magnitude of the reduction in bacterial numbers was highly significant $(\mathrm{P}<0.01)$ after 24 hours as the average $\log$ reductions in counts were $1.5,2.7,2.3$ and $3 \log$ cycles in samples treated with $2 \%$ acetic acid, $4 \%$ acetic acid, $2 \%$ lactic acid and $4 \%$ lactic acid respectively. Meanwhile, after 24 hours the control meat allowed increase ( $0.4 \mathrm{log}$ cycles) in the microbial population. According to literatures, a bacterial reduction up to 3 Log can be achieved, but the highest reductions are generally observed with high concentration (Prasai et al., 1992; Van -Netten et al., 1994, Jensen et al., 2002; 
Fabrizio et al., 2004).The antimicrobial properties of acid are attributed to the undissociated molecule and to a reduction of $\mathrm{pH}$ below the level at which the growth of many bacteria is inhibited (Nykanen et al., 1998).Undissociated weak acids possess the ability to cross membranes of microorganisms, become dissociated inside the cell and acidify the cell interior. The intracellular dissociation of acid results in denaturation of enzymes and disruption of membrane (Freese et al., 1973).

The increase in storage time produced increase in APCs, the increase was more rapid in control sample. At the day 3 of storage, mean total APCs of control $\left(5.3 \pm 0.3 \log _{10} \mathrm{CFU} / \mathrm{g}\right)$ exceeded the maximal recommended limit of $5 \mathrm{log} \mathrm{CFU} / \mathrm{g}$ for total APCs in raw and chilled meat (E.O.S.Q.C. ,2001 and 2004). This differed significantly $\quad(P<$ 0.05 ) with the APCs in $2 \%$ A.A, $4 \%$ A.A and $2 \%$ L.A. treated meat samples and highly significantly $(\mathrm{P}<0.01)$ as compared with the value of APCs in $4 \%$ lactic acid treated meat samples on the same day. Spoilage changes with greenish discoloration and putrid odor were noticed in untreated control samples on $5^{\text {th }}$ day with corresponding increases in APCs to $7.3 \pm 0.2 \log _{10} \mathrm{CFU} / \mathrm{g}$. Bacterial counts are generally thought to be an indicator of early spoilage, with "off" odors becoming apparent when bacterial number reach approximately $10^{7}$ cells per $g$ of meat (Borch et al., 1996). It is accepted that a number of $7 \mathrm{log}$ $\mathrm{CFU} / \mathrm{g}$ is the approximate point at which meat reaches spoilage as to become unsalable (Dainty and Mackey, 1992). The APCs values were lower than $5 \log$ CFU/g in day 7 in samples treated with $2 \%$ acetic acid, $2 \%$ lactic acid and $4 \%$ acetic acid and in days 9 in group treated with $4 \%$ lactic acid .These results indicate that acetic or lactic acid treatments of beef reduced microbial count immediately after treatment, moreover, a residual influence was observed and inhibited bacterial growth as compared with the non-treated control sample. At day $9^{\text {th }}$ of storage, sample containing lactic acid $4 \%$ had a highly significant lower APCs $\left(4.8 \pm 0.3 \log _{10} \mathrm{CFU} / \mathrm{g}\right)$ than the maximal recommended limit and the effect of lactic acid is apparent even at the end of the 9 days storage, while all other samples exhibited a higher APC indicating that 4\% L.A. was more effective. The differences in total aerobic counts between treated and control samples at the end of the storage were 2-3 log cycles order.

4.1.2.Psychrophilic counts:

Although the effect of the acid spray treatments was similar in both psychrophilic and aerobic plate counts, the growth of psychrophilic during the cold storage was faster than that of mesophilic. The initial PTCs in beef samples ranged from 2.7- 2.9 $\log _{10} \mathrm{CFU} / \mathrm{g}$ (Fig. 2). The 
initial delay of PTCs growth in treated samples can be ascribed to the effect of acetic acid and lactic acid on the surface layer. Length of refrigerated storage had significant effect on PTCs, which tended to increase as the storage time increased. During storage significantly higher counts $(\mathrm{P}<0.01)$ of psychrophilic bacteria were observed in control sample compared with those sprayed with acids. Also, psychrophilic counts in samples treated with $4 \%$ lactic acid were significantly lower $(\mathrm{P}<0.01)$ than other samples.

The changes in PTC were approximately similar to those of APC, with control being the highest at day $3\left(4.9 \pm 0.1 \log _{10} \mathrm{CFU} / \mathrm{g}\right)$ followed by samples treated with A.A. $2 \%\left(3.7 \pm 0.4 \log _{10} \mathrm{CFU} / \mathrm{g}\right)$, then $4 \%$ A.A. $\left(3.4 \pm 0.4 \log _{10} \mathrm{CFU} / \mathrm{g}\right)$, then $2 \%$ L.A. $\left(3.2 \pm 0.3 \log _{10} \mathrm{CFU} / \mathrm{g}\right)$ while lower counts were detected in samples treated with lactic acid $4 \%$ L.A.(2.6 $\pm 0.5 \quad \log _{10} \quad$ CFU/ g). Spoilage changes with greenish discoloration and putrid odor were noticed in untreated control samples on $5^{\text {th }}$ day with corresponding increases in total psychrophilic counts to $7.9 \pm 0.4 \log _{10} \mathrm{CFU} / \mathrm{g}$. This reduction in color acceptability has been shown to be related to the growth of psychrophilic bacteria at the meat surface (Jeremiah et al., 1972). In this concern, Kandeepan and Biswas (2007) reported that the increased enzyme activity of psychrophilic at low temperature hugely contributed to deterioration of meat quality. At day 9 of storage, samples containing L.A $4 \%$ had a lower PTC (5.1 \pm 0.6 $\log _{10} \mathrm{CFU} / \mathrm{g}$ ) while all other samples exhibited a higher PTC indicating that lactic acid $4 \%$ is more effective.

4.1.3. Total coliform counts:

The initial coliform counts of samples were low (1.6-1.9 $\log _{10}$ $\mathrm{CFU} / \mathrm{g}$ ) .Coliform counts increased from $1.6 \pm 0.1 \log _{10} \mathrm{CFU} / \mathrm{g}$ in control samples at day 0 to a count of $3.5 \pm 0.30 \log _{10} \mathrm{CFU} / \mathrm{g}$ by day 9 of storage (Fig.4). The growth of coliform was slower than that of APCs or PTCs. Undetectable level was noticed in all acid treated samples during first 3 days of storage but it reached counts of $1.8 \pm 0.2,1.7 \pm 0.2$ and $1.6 \pm 0.1$ $\log _{10} \mathrm{CFU} / \mathrm{g}$ in meat samples treated with $2 \%$ A.A, $4 \%$ A.A and L.A $2 \%$, respectively by day 9 of storage. This was most likely due to the low initial coliform populations present in samples. Also, coliforms do not grow well at $4 \stackrel{\mathrm{C}}{\mathrm{C}}$ that may also explain why reductions were not evident. However, even any small reduction in microbial counts represents a prolongation of the shelf-life. However, during storage time, sample treated with $4 \%$ L.A. showed reduced coliform growth to undetectable level .Castillo et al. (2001) found that Log coliform count were consistently reduced to undetectable levels when $4 \%$ L.A sprayed on 
chilled beef carcasses. They added that the small reductions observed for coliforms are attributable to counts on untreated carcasses already being near the lower detection limit of the counting method. In this concern, Gill and Landers (2003) stated that when relatively high levels of bacterial contamination were present, spray washing reduced bacterial counts, but it had little effect at relatively low levels. However, Gill and Badoni (2004), reported a reduction in coliform population of meat treated with $4 \%$ lactic acid by $>/=1.5 \log$ unit during chilling storage.

Comparing the effects of the two acids, the present results in Tables (1, 2 and 3) revealed that lactic acid inhibited the growth of bacteria effectively, the microbial counts in samples treated with lactic acid were lower than that recorded in acetic acid treated samples in both concentrations. Our results were in agreement with Lin and Chuang (2001) who reported that lactic acid was more inhibitory toward microorganisms than acetic acid in pork loin chop. Also Samelis et al. (2002) reported that lactic acid is higher in effectiveness than acetic acid against inhibiting the growth of microorganisms.

From the present results, it has been found that treatment with $4 \%$ of both acid appears to be more effective when compared to $2 \%$ solutions .This may be due to the reason that acid exhibits effective antimicrobial action, only when appropriate amounts of undissociated molecules of that acid penetrate bacterial cell by means of diffusion and interfere with intra cellular enzymes (Smulders et al., 1986).Increasing the amount of acid applied or lowering the $\mathrm{pH}$ will increase the amount of undissociated acid molecules, thereby, antimicrobial action. The results of present study are in confirmation with the work done by Saoji et al. (1990) who observed similar results in buffalo meat streaks treated with progressively higher concentration of lactic acid solutions. It is very certain that the efficacy of organic acid depends on the load of initial microbial contamination as well as the $\mathrm{pH}$ and the concentration of the organic acid solution (Koutsoumanis et al., 2006).

It is evident from the data of bacteriological evaluation that the treatment with $4 \%$ lactic acid was more effective in delaying the microbial growth and extended the shelf life of the meat .This finding is consistent with that reported by Castelo et al. (2001) they reported that increased lactic acid concentration up to $4 \%$ resulted in increased reduction rates in the numbers of microorganisms on carcasses surface.

4.2.Sensory evaluation:

Sensory characteristics, particularly the odor and color of fresh meats are extremely important from the standpoint of consumer acceptability (Ingram and Simonsen, 1980). 


\subsubsection{Sensory Evaluated Color:}

Effect of lactic acid and acetic acid treatments (2 and $4 \%$ ) on color of meat samples were summarized in Table (1).Initially, treatment with $2 \%$ L.A. had minimal effect on the color of meat, however this often disappears or becomes less evident after chilling. Meanwhile, samples treated with $2,4 \%$ A.A. and $4 \%$ L.A. showed discoloration (bleaching) as compared to the control on $30 \mathrm{~min}$. of display. At days 1 of display all treatments except $2 \%$ L.A. showed discoloration compared with the control .Meat treated with $2 \%$ L.A. was redder in color when compared with the control on days 1 to 3 of display and there was an improved in the sensory scores until 3 days $(\mathrm{P}<0.01)$ with no further improvement when storage was extended to 9 days. Saoji et al. (1990) also observed similar discoloration in buffalo meat streaks treated with $4 \%$ lactic acid. No effect of spraying beef carcasses with lactic acid (2\%) was observed by Prasai et al. (1991). Meanwhile, Stivarius et al. (2002) reported that acetic acid caused changes in ground beef color and odor characteristics. Also Pipek et al. (2005) observed that the surface spraying of beef muscle by $2 \%$ lactic acid had a negligible effect on the color. At 3 days of display, reduction of color score of control group was observed. This reduction in color acceptability has been shown to be related to the growth of mesophilic and psychrophilic bacteria at the meat surface. The color scores decreased with increasing concentrations of acids and the days of storage with better color shown in samples treated with $2 \%$ lactic acid during first 3 days followed by samples treated with $4 \%$ lactic acid and to a lesser extent to samples treated with acetic acid in both concentrations. At 3 days, sensory evaluation indicated that the samples treated with $2 \%$ and $4 \%$ acetic acid were exhibited reduction in color score as compared to samples treated with lactic acid. Color deterioration of whole muscle cut surfaces have been reported with acetic acid treatment (Mikel et al.,1996). In this concern, 2 percent acetic acid and 5 percent acetic acid had been reported to cause premature browning of lean meat color (Miller, 2005).

As bacteria grow on the meat surface they accelerate the oxidation of meat pigments which results in a progressive deterioration of the acceptable red color and the appearance of varying degrees of brown surface discoloration.After beef has been refrigerated for 5 days, control meat lost red color, turn brown, had an off-odor, and be sticky to the touch and become visually unacceptable to panelist indicating shelf life of about 3-<5 days. Similar results were reported by Abd El-Rhaman et al. (2007) who found an unacceptable color and off-odor after 5 days of storage at $4^{\circ} \mathrm{C}$ of air-packaged beef .Microbial results appeared to be 
consistent with results of color. In this respect, Koutsoumanis et al. (2006) reported that the micro-organisms can cause discoloration, offodors, off-flavors, gas formation and/or changes in texture and slime. The surface of the samples treated with $2 \%$ L.A. was not severely discolored and remained acceptable even after 7 days storage. Four percent lactic acid treatments controlled microbial load more significantly among the treatments. However, these sample could not keep their color stable. In this concern, Sundar and Zhan( 2006) reported that 4 or $6 \%$ lactic acid spray treatment could be better if color and lipid oxidation could be stabilized by appropriate stabilizers.

\subsubsection{Sensory Evaluated Odor:}

The changes in sensory evaluated odor for all studied samples showed similar trends to those found for sensory evaluated color. After 30 min. of acid spray, highly significant $(\mathrm{P}<0.01)$ change in odor was detected in samples treated with acetic acid either 2 or $4 \%$ concentrations (Table 2) .The panelists characterized the odor as mild acidic (vinegar odor). However, no change in odor was noticed in sample sprayed with $2 \%$ lactic acid and a significant $(\mathrm{P}<0.05)$; mild acidic odor was detected in samples treated with $4 \%$ lactic acid solution. Saoji et al. (1990) also observed a mild acidic odor in buffalo meat streaks treated with $4 \%$ lactic acid solution .At $3^{\text {rd }}$ day, the samples treated with acetic acid continued to have the strongest acid odor as compared to other samples. After $5^{\text {th }}$ days of storage, control sample exhibited significant $(\mathrm{P}<0.01)$ unpleasant odors. Data from sensory analysis confirmed those from microbiological tests. Panelists rejected control samples after 5 days, where samples reached or exceeded the spoilage onset $\left(10^{7}-10^{8} \mathrm{CFU} / \mathrm{g}\right)$. The offensive odor and change in color were appeared when the count reached $10^{7} \mathrm{CFU} / \mathrm{g}$ (Byun et al, 2003). Sensory evaluation indicated that the samples treated with $2 \%$ and $4 \%$ acetic acid were unacceptable on the $9^{\text {th }}$ day of storage. The increased enzyme activity of psychrophilic at low temperature hugely contributed to deterioration of meat quality (Kandeepan and Biswas, 2007). At $9^{\text {th }}$ day storage samples treated with L.A. had small to moderate off-odor. Data from sensory analysis confirmed those from microbiological tests.

\subsubsection{Sensory overall appearance :}

Appearance of beef in the retail case affects acceptability of the product to consumers bright-red lean color suggests freshness to retail customers (Liu et al., 1996).

Time at which samples were scored moderately undesirable in overall appearance by members of a panel was considered unacceptable. 
Acid treated samples had mean overall appearance scores of 3 (moderately undesirable) at 7 to 9 days whereas control group had mean overall appearance scores of 3 at $5^{\text {th }}$ day (Table 3).Sensory data and microbial populations were in general agreement and showed correlations across the observed time periods. Off-odors, declining color scores and increased surface discoloration became detectable which corresponded with peak bacterial growth occurring at $5^{\text {th }}$ days in control group. From the sensory and overall appearance results, it could be concluded that the shelf life of meat treated with acid could be extended from 2-4 days under refrigerator storage. Data from sensory analysis confirmed those from microbiological tests. Kofitsyo(1988) recorded that spraying the meat surface of skinned cow heads with lactic acid resulted in reduction in total viable counts of bacteria and the shelf lives were observed to have been extended for about three days at $4^{\circ} \mathrm{C}$. The predominant reason for meat shelf life is microbial spoilage activity (Koch et al., 2009).There have been several studies investigating the use of organic acids as sanitizing solutions to improve shelf-life and safety of fresh meat (Hardin et al., 1995 and Kochevar, 1997 ).

From microbial quality standpoints, shelf-life of acid treated samples was 7 -9 days according to treatment used against 3 days in untreated samples.

24.3.Physicochemical -evaluation:

4.3.1. $\mathrm{pH}$ Changes:

Changes in $\mathrm{pH}$ of meat as affected by lactic and acetic acid treatments during storage are presented in Table (4). The initial mean $\mathrm{pH}$ values of all meat samples ranged from $5.63 \pm 0.01$ to $5.75 \pm 0.01$ which reflected the acceptable quality state of meat samples. After acid treatment, the $\mathrm{pH}$ values of acid sprayed samples dropped significantly ( $\mathrm{P}<0.01)$. Mean $\mathrm{pH}$ values recorded after $30 \mathrm{~min}$. in control, $2 \%$ A.A., $4 \%$ A.A, $2 \%$ L.A. and $4 \%$ L.A. treated meat samples were 5.89 \pm 0.02 , $4.94 \pm 0.01,4.82 \pm 0.03,5.12 \pm 0.01$ and $5.04 \pm 0.01$. During the initial storage period, the $\mathrm{pH}$ of treated meat samples was consistently low .The low $\mathrm{pH}$ values of samples treated with acetic and lactic acid treated samples may have altered the growth of spoilage microorganisms, hence, extending the shelf life of the meat. One effective means of limiting microbial growth is to increase the acidity of beef, thereby creating an unfavorable environment for the growth. The lower $\mathrm{pH}$ disturbs the homeostasis of the bacterial cells, including pathogens and spoilage bacteria (Leistner, 2000).

A gradual increase in $\mathrm{pH}$ was observed in control meat sample. On $5^{\text {th }}$ day, the $\mathrm{pH}$ of control sample $(6.58 \pm 0.01)$ was significantly 
higher $(\mathrm{P}<0.01)$ than the acid treated meat samples. The increase in $\mathrm{pH}$ values reflected the production of alkaline bacterial metabolites in spoiling meat (Kyrana et al., 1997) and coincided with the increase in microbial population, sensory changes and total volatile basic nitrogen (TVB-N). In general, bacteria prefer a $\mathrm{pH}$ near neutrality (Walker and Betts ,2000). Upon storage, the $\mathrm{pH}$ values of all treated samples increased gradually which was also observed by Jayesh and Venkataramanujam (2000). Comparing acid treatment used, lactic acid treated samples had a $\mathrm{pH}$ decline during the initial 3 days then increased gradually, giving a final $\mathrm{pH} 0.24$ unit above the initial reading above the initial reading. Meanwhile, samples treated with acetic acid had a lower $\mathrm{pH}$ during storage giving final readings about $0.16-0.33 \mathrm{pH}$ unit below the initial readings. The lower capacity of acetic acid to enter bacteria cell is compensated by their greater capacity to dissociate inside the cell and thus acidify the cell cytoplasm (Young and Foegeding, 1993). Watts (1954) points out that lower $\mathrm{pH}$ values associated with extended periods of storage may accelerate metmyoglobin formation in fresh meats. In this concern, Abril et al.( 2002) concluded that the low pH affects beef color by promoting oxidation of the haem pigments from the purple or red myoglobin and oxymyoglobin to the brown met myoglobin. Data from $\mathrm{pH}$ confirmed those from sensory analysis after 3 days, sensory evaluation indicated that the samples treated with $2 \%$ and $4 \%$ A.A. were exhibited reduction in color score as compared to samples treated with lactic acid and turn brown on the $5^{\text {th }}$ day of storage.

4.3.2. Total volatile basic nitrogen (TVB-N):

Total volatile basic nitrogen (TVB-N) contents of control and acid treated samples were tabulated in Table (5). Generally, the significantly higher $\quad(\mathrm{P}<0.01)$ TVB-N content was found in control beef sample when compared with acid treated samples for the same storage period. For the control group, TVB-N content increased rapidly and reached $25.89 \pm 0.23 \mathrm{mg} / 100 \mathrm{~g}$ after 5days of storage. Data from sensory analysis and microbiological tests confirmed those where control sample reached or exceeded the spoilage onset $\left(10^{7}-10^{8} \mathrm{CFU} / \mathrm{g}\right)$. However, all samples sprayed with acids had TVB-N contents less than $20 \mathrm{mg} / 100 \mathrm{~g}$ within 5 days of storage which meet the safety and quality standards .Since the total bacteria were low in number, the corresponding TVB-N value was equally low. TVB-N are products of bacterial spoilage and it is often used as an index to assess the keeping quality and shelf-life (Goulas et al., 2005). TVB-N values of fresh and good quality meat are less than $20 \mathrm{mg} / 100 \mathrm{~g}$. TVB-N values in the range $20-25 \mathrm{mg} / 100 \mathrm{~g}$ and above $25 \mathrm{mg} / \mathrm{g}$ indicate meat that are slightly 
decomposed/ edible and decomposed/ inedible, respectively (Lannelongue et al., 1982).The increase in storage time produced increase in TVB-N values of all groups which were related to bacterial growth. The TVB-N values were higher in acetic acid sprayed samples than that of lactic acid sprayed samples at the same concentrations used for the same storage period which coincides with bacterial counts and sensory evaluation. At $7^{\text {th }}$ day, all samples had TVB-N contents more than $20 \mathrm{mg} / 100 \mathrm{~g}$ except sample treated with lactic acid $4 \%$ which showed the lowest TVB-N content and reached $22.23 \pm 0.03$ at $9^{\text {th }}$ day of storage. The present results were in accordance with the results of bacterial counts . Byun et al. (2003) reported that TVB-N contents showed the best correlation with bacterial counts for beef. They added that TVB-N could potentially be used as indicators in predicting the microbial quality of beef during chilled storage.

\section{Conclusion:}

Microbial population that comes in contact with fresh meat during slaughtering, dressing and processing presents a challenging problem to the meat industry. Results from the present study suggest that lactic acid and acetic acid treatment improved the microbial quality of raw meat. In the light of data obtained from the analyses of the bacteriological, sensory and chemical qualities it was concluded that $2 \%$ lactic acid spray treatment had less effect on odor and did not negatively influence the surface color, it can be used in slaughterhouses to comply with food safety regulations, prolong the shelf-life of carcasses and to increase the safety of meat. Reduction of pathogen prevalence on meat post-slaughter leads to a reduced probability that errors occurring in subsequent parts of the food chain will lead to foodborne illness and yield products that should be safe for consumption following proper cooking and serving.

\section{REFERENCES}

Abril, M.; Campo, M.M.; Onenc, A.; Saudo, C., Albert, P. and Negueruela, A.I. (2002): Beef color evolution as a function of ultimate $\mathrm{pH}$. J. Meat Sci., 58: 69-78.

AMSA. ( 1991): Guidelines For Meat Color Evaluation. National Live Stock and Meat Board, Chicago, IL.

AOAC (Association of Official Chemists). (1984). Official method of analysis. $14^{\text {th }}$ Ed., Washington. 
Berry, E.D. and Cutter, C.N. (2000): Effects of acid adaptation of Escherichia coli O157:H7 on efficacy of acetic acid spray washes to decontaminate beef carcass tissue. Appl. and Environ. Microbiol., 66:1493- 1498.

Bolder, N. M. (1997): Decontamination of meat and poultry carcass. Trends in Food Sci. and Technol., 8:221- 227.

Borch, E.; Kant-Muermans, M. L. and Blixt, Y. (1996): Bacterial spoilage of meat and cured meat products. Int. J. of Food Microbiol., 33:103-120.

Branen A.L.; Davidson, P.M. and Salminen, S. (1990): Food Additives. Marcel Dekker, Inc., New York, NY.

Brunso K., Bredahl L., Grunert K.G., Scholderer J. (2005):Consumer perception of the quality of beef resultingfrom various fattening regimes. Livestock ProductionScience, 94, 83-93.

Byun, J.S.; Min, J.S.; Kim, I.S.; Kim, J.W.; Chung, M.S. and Lee, M. (2003): Comparison of indicators of microbial quality of meat during aerobic cold storage. J Food Prot., 66(9):1733-1737.

Castillo, A.; Lucia, L.M.; Mercado, I. and Acuff, G.R.(2001): In-Plant evaluation of a lactic acid treatment for reduction of bacteria on chilled beef carcasses. J. Food Prot., 64: 738-740.

Cherrington, C.A.; Hinton, M.G.; Person, R. and Chopra, I.J. (1991): Organic acids as microorganisms decontaminators. J. Appl. Bacteriol., 70: 156-172.

Dainty, R.H. and Mackey, B.M. (1992): The relationship between the phenotypic properties of bacteria from chill-stored meat and spoilage processes. J. Appl. Bacteriol., 73: 103-114.

Dickson, J.S. and Anderson, M.E. (1992): Microbiological decontamination of food animal carcasses by washing and sanitizing system. J. Food Sci., 48: 156-163.

Dincer, A.H. and Baysa, T. (2004): Decontamination techniques of pathogen bacteria in meat and poultry. Crit. Rev. Microbiol., 30: 197-2.

E.O.S.Q.C. (2001): Egyptian standards for requirement of chilled beef, No., 3602.

E.O.S.Q.C. (2004): Egyptian standards for requirement of fresh meat. No., 4334.

Fabrizio, K.A. and Cutter, C.N. (2004): Comparison of electrolyzed oxidizing water with other antimicrobial interventions to reduce pathogens on fresh pork. Meat Sci. 68, 463-468.

Freese, E.; Sheu, C. W. and Galliers, E. (1973): Function of lipophilic acids as antimicrobial food additives. Nature. 241: 321-325. 
Gill, C.O. (1980): Total end intramuscular bacterial populations of carcasses and cuts. Proc. $33^{\text {rd }}$ Ann. Reciprocal Meat Conf., 33: 47-53.

Gill, C.O. and Badoni, M. (2004): Effects of peroxyacetic acid, acidified sodium chloride or lactic acid solutions on the microflora of chilled beef carcasses. Int. J. Food Microbiol., 15; 91 (1): 43-50.

Gill, C. O. and Landers, C. (2003): Microbiological effects of carcass decontaminating treatments at four beef packing plants. Meat Sci., 65(3), 1005-1011.

Gram, L.; Ravn, L. Rasch, M.; Bruhn, J. B.; Christensen, A. B. and Givskov, M. (2002): Food spoilage interactions between food spoilage bacteria. Int. J. Food Microbiol. 78:79-97.

Goulas, A.E.; Chouliara, I.; Nessi, E.; Kontominas, M.G. and Savvaidis, I.N.(2005):Microbiological, biochemical and sensory assessment of mussels (Mytilus galloprovincialis) stored under modified atmosphere packaging. J. Appl. Microbiol., 98: 752-760.

Eneji, C; A.; Ikpeme, C. E. and Ubua, J. (2007): Effect of Refrigeration and Frozen Storage on the Shelf-life of Beef Purchased from Local Markets and Abattoir in Calabar Metropolis-Nigeria. Pakistan Journal of Nutrition, 6 (6): 576-581.

Hardin, M. D.; Acuff, G. R.; Lucia, L. M.; Oman, J.S. and Savell, J.W. (1995): Comparison of methods for decontamination from beef carcass surfaces. J. Food Prot., 58: 368-374.

Hilario, E.; Buckley, T. R. and Young, J. M. (2004): Improved resolution of the phylogenetic relationships among Pseudomonas by the combined analysis of atpD, carA, recA and $16 \mathrm{~S}$ rDNA. Antonie Leeuwenhoek., 86:51-64.

Huffman, R.D. (2002): Current and future technologies for the decontamination of carcass and fresh meat. Meat Sci., 62: 285294.

Hunt, M. C., Acton, J. C., Benedict, R. C., Calkins, C. R., Cornforth, D. P., Jeremiah, L. E., Olson, D. G., Salm, C. P., Savell, J. W. and Shivas, S. D. (1991): AMSA guidelines for meat color evaluation. In Proceedings $44^{\text {th }}$ Annual Reciprocal Meat Conference (ARMC91):3-17.

Inal, T.(1992): Food Hygiene: The Safety Control of Foods from Animal Origin. Final Ofset, Istanbul, Turkey.

Ingram, M. and B. Simonsen. (1980): Meats and meat products, chap. 15. In J. H. Silliker et al. (eds.). Microbial ecology foods, vol. 2. Academic Press, New York. 
Jayesh, V. and Venkataramanujam, V. ( 2000): Effect of chilling and freezing on physico chemical quality of mutton. Indian Vet. J., 79: 743-745

Jensen, T. and Christensen, H. (2002): Full scale test with decontamination of pig carcasses with hot water. $48^{\text {th }}$ ICOMST in Roma.

Jeremiah, L. E.; Carpenter, Z. L. and Smith, G. C. (1972): Beef color as related to consumer acceptance and palatability. J. Food Sci., 37:476-479.

Institute of Food Technologists (IFT),( 2002): Expert Report on Emerging Microbiological Food Safety Issues, Implications for Control in the 21st Century. Inst. of Food Technol. Chicago, IL., pp: 107.

ISO 4833(2003): Microbiology of food and animal feeding stuffs Horizontal methods for the enumeration of microorganisms. Colony-count technique at $30{ }^{\circ} \mathrm{C}$.

ISO 17410(2001): Microbiology of food and animal feeding stuffs Horizontal methods for the enumeration of psychotropic microorganisms.

ISO 4832(2006): Microbiology of food and animal feeding stuffs Horizontal method for the enumeration of coliforms Colony count technique.

Jay, J.M.( 1992): Intrinsic and Extrinsic Parameters of Food that Affect Microbial Growth. In: Modern Food Microbiology, (Ed.). VI Book, New York, pp: 38-62.

Kandeepan, G. and Biswas, S. (2007): Effect of low temperature preservation on quality and shelf life of buffalo meat. Am. J. Food Technol., 2: 126-135.

Koch, A.G.; Christensen, H. Sorensen, P.E. and Meinert, L. (2009): Requirements to shelf-life of fresh meat and meat products. Proceedings of the 55th Int. Con. Meat Sci. and Technol., Copenhagen, Denmark, pp: 1273-1276.

Kochevar, S.L, Sofos, J.N.; LeValley, S.B. and Smith, G.C. (1997):

Effect of water temperature, pressure and chemical solution of removal of fecal material and bacteria from lamb adipose tissue by spray-washing. J. Meat Sci., 45: 377-388.

Kofitsyo, S. C. (1988): The effect of lactic acid sprays on the keeping qualities of meat during storage. Int. J. Food Microbiol . 7: (1) 17.

Koutsoumanis, K.P.; Geornaras, I. and Sofos, J .N. (2006): Microbiology of Land Animals. In: Handbook of Food Sci. 
Technol. and Engin., Hui, Y.H. (Ed.)., CRC Press, Taylor and Francis Group, Boca Raton, FL., (1): 521-524.

Kyrana, V. R.; Lougovious, V.P. and Valsamis, D.S.(1997) :Assessment of shelf-life of maricultured gilthead sea bream (Sparus aurata) stored in ice. Int. J. Food Sci. Technol., 32: 339-347.

Lahr, J.A.(1996): Beef carcass microbial contamination post slaughter numbers of bacteria, sources of contamination and variability. Proceedings of 49th Annual Reciprocal Meats Conference, (ARMC'96), Provo, Utah, Chicago, IL. pp: 132-137.

Lannelongue, M.; Finne, G.; Hanna, M.O.; Nickelson, R., Vanderzani, $C$. (1982): Microbiological and chemical changes during storage of swordfish (Xiphias gladius) steaks in retail packages containing CO2-enriched atmospheres. J. Food Prot., 45:11971203.

Leistner, L. (2000): Basic aspects of food preservation by Hurdle Technology. Int. J. Food Microbiol. 55: 181-186.

Lin, K.W. and Chuang, C.H. (2001): Effectiveness of dipping with phosphate, lactate and acetic acid solutions on the quality and shelf life of pork loin chop. J. Food Sci., 66: 494-499.

Liu, Q.; Scheller, K. K. ; Arp, S. C. ; Schaefer, D. M. and Frigg, M.(1996):Color coordinates for assessment of dietary vitamin $\mathrm{E}$ effects on beef color stability. J. Anim. Sci., 74:106-116.

Mikel, W.B.; Goddard, B.L. and Bradford, D.D. (1996): Muscle microstructure and sensory attributes of organic acid treated beef strip loins. J. Food Sci., 61: 1058-1061.

Miller, M. (2005): Application of Antimicrobial Treatments in a Commercial Simulation to Reduce E. coli O157:H7 and Salmonella spp. in Beef Trim and in Ground Beef . Ph.D., Chance Brooks, Ph.D. and Mindy Brashears, Ph.D., Texas Tech. University.

Nykanen, A., Lapretelainen, A.; Hietanen, R.M. and Kallio, H. (1998): The effect of lactic acid, nisin, whey permeates sodium chloride and related combinations on aerobic plate count and the sensory characteristics of rainbow trout. Technol., 31: 286-290.

Pipek, P.; Houska, M. ; Jelenikova, J.; Kyhos, K.; Hoke K. and Sikulova, M. (2005): Microbial decontamination of beef carcasses by combination of steaming and lactic acid spray. J. Food Engin. 67(3):309-315.

Prasai, R. K. ;Acuff, G. R. ;Lucia, L. M. ; Morgan, J. B.; May, S. G. and Savell, J. W. (1992): Microbiological effects of acid 
decontamination of pork carcasses at various locations in processing. Meat Sci., 32, (4) : 413-423.

Ramirez, A.J.; Acuff, G.R.; Lucia, L.M. and Savell, J.W. (2001): Research Note: Lactic acid and trisodium phosphate treatment of lamb breast to reduce bacterial contamination. J. Food Prot., 64: 1439-1441.

Samelis, J.; Sofos, J. N.; Ikedal, J. S.; Kendall, P. A. and Smith, G. C. (2002): Exposure to non-acid fresh meat decontamination washing fluids sensitizes Escherichia coli O157:H7 to organic acids. The Society for Appl. Microbiol., Letters in Appl. Microbiol., 34: 7-12.

SAS Institute (2000): The SAS System for Windows (Release 8.01). SAS Inst. Inc., Cary, NC.

Selvan, p.; Mendiratta, S.K. ;.Porteen, K. and Bhilegaonkar, K.N.(2007): Int. J. Food Safet., 9: 29-36.

Seideman, S. C. ; Cross, H. R. , Smith, G. C. and Durland, P. R.(1984):

Factors associated with fresh meat color: a review J. of Food Qual.., 6(3): 211-237.

Sofos, J.N. and Smith, G.C. (1998): Nonacid meat decontamination technologies: Model studies and commercial applications. Int. J. Food Microbiol. 44: 171-188.

Saoji, S.S.; Sherikar, A.T.; Bhilegaonkar, K.N. and Karkare, U.D.

(1990): Preservative effect of acetic and lactic acids on buffalo meat stored at refrigeration temperature. J. Bombay Vet. Coll.,

2(1): 37-45.

Siragusa, G.A. and Dickson, J.S. (1992): Inhibition of Listeria monocytogenes on beef tissue by application of organic acids immobilized in calcium alginate gel. J. Food Sci., 57: 293-296.

Stivarius, M.R.; Pohlman, F.W.; McElyea, K.S. and Apple, J.K. (2002): The effects of acetic acid, gluconic acid and trisodium citrate treatment of beef trimmings on microbial, color and odor characteristics of ground beef through simulated retail display. Meat Sci., 60 (3): 245-252.

Strange, E.D., Benedict, R.C. Gugger, R.E. Metzger, V.G. and Swift. C.E. (1974):Simplified methodology for measuring meat color. J. Food Sci. 39: 988-992.

Sundar, S. and Zhang, M.( 2006): Effect of lactic acid pretreatment on the quality of fresh pork packed in modified atmosphere. J. Food Engin., 72(3): 254-260. 
USDA/FSIS (2004): Safe and suitable ingredients used in the production of meat and poultry products. FSIS Directive 7120.1 Amendment 6, USDA-FSIS.

Van Netten, P.; Huis In 't Veld, J. and Mossel, A.A., (1994):. An in-vitro meat model for the immediate bactericidal effect of lactic acid decontamination on meat surfaces. J. Appl. Bacteriol., 76: 49-54.

Walker, S.J. and Betts, G. (2000): Factors Affecting the Microflora of Chilled Foods. In: Chilled Foods, Stringer, M. and C. Dennis, (Eds.). Woodhead Publishing, London, pp: 157-178.

Watts, B.M. (1954): Oxidative rancidity and discoloration in meat. Adv. Food Res., 5:1-52.

Young, K. M. and Foegeding, P. M. (1993): Acetic, lactic and citric acids and $\mathrm{pH}$ inhibition of Listeria monocytogenes and the effect on intracellular pH. J. Appl. Bacteriol., 74 515-520. 